\title{
GMR
}

\section{Genetic diversity of Bromeliaceae species from the Atlantic Forest}

\author{
Y. Sheu ${ }^{1}$, A.S. Cunha-Machado ${ }^{2}$, A.B.P.L. Gontijo ${ }^{3}$, F.C. Favoreto ${ }^{4}$, \\ T.C.B. Soares ${ }^{5}$ and F.D. Miranda ${ }^{1}$ \\ ${ }^{1}$ Departamento de Biologia, Centro de Ciências Exatas Naturais e da Saúde, \\ Universidade Federal do Espírito Santo, Alegre, ES, Brasil \\ ${ }^{2}$ Instituto Nacional de Pesquisas da Amazônia, Manaus, AM, Brasil \\ ${ }^{3}$ Departamento de Ciências Agrárias e Biológicas, \\ Centro Universitário Norte do Espírito Santo, \\ Universidade Federal do Espírito Santo, São Mateus, ES, Brasil \\ ${ }^{4}$ Instituto Federal de Educação, Ciência e Tecnologia do Espírito Santo, \\ Piúma, ES, Brasil \\ ${ }^{5}$ Departamento de Farmácia e Nutrição, \\ Centro de Ciências Exatas Naturais e da Saúde, \\ Universidade Federal do Espírito Santo, Alegre, ES, Brasil \\ Corresponding author: Y. Sheu \\ E-mail: yumisheu@hotmail.com
}

Genet. Mol. Res. 16 (2): gmr16029636

Received January 31, 2017

Accepted March 8, 2017

Published April 20, 2017

DOI http://dx.doi.org/10.4238/gmr16029636

Copyright $(2017$ The Authors. This is an open-access article distributed under the terms of the Creative Commons Attribution ShareAlike (CC BY-SA) 4.0 License.

\begin{abstract}
The Bromeliaceae family includes a range of species used for many purposes, including ornamental use and use as food, medicine, feed, and fiber. The state of Espírito Santo, Brazil is a center of diversity for this family in the Atlantic Forest. We evaluated the genetic diversity of five populations of the Bromeliaceae family, including specimens of the genera Aechmea, Billbergia (subfamily Bromelioideae), and Pitcairnia (subfamily Pitcairnioidea), all found in the Atlantic Forest and distributed in the state of Espírito Santo. The number of alleles per locus in populations ranged from two to six and the fixation
\end{abstract}

Genetics and Molecular Research 16 (2): gmr16029636 
index (F), estimated for some simple sequence repeats in bromeliad populations, was less than zero in all populations. All markers in the Pitcairnia flammea population were in Hardy-Weinberg equilibrium $(\mathrm{P}<0.05)$. Moreover, significant deviations from Hardy-Weinberg equilibrium were observed at some loci in populations of the five bromeliad species. In most cases, this can be attributed to the presence of inbreeding or the Wahlund effect. The genetic diversity indices of five species showed greater allelic richness in P. flammea (3.55). Therefore, we provide useful information for the characterization of genetic diversity in natural populations of Aechmea ramosa, Aechmea nudicaulis, Billbergia horrid, Billbergia euphemia, and P. flammea in Atlantic Forest remnants in the south of Espírito Santo state.

Key words: Microsatellites; Bromeliads; Genetic diversity

\section{INTRODUCTION}

The Bromeliaceae family includes approximately 60 genera and 3170 species (Luther, 2008; Givnish et al., 2011). The only exception to the uniquely American pattern of distribution is the Pitcairnia feliciana species (A. Chev.) Harms \& Mildbr, which is located in the region of Guinea, along the West Africa coast (Benzing, 2000). The Bromeliaceae family is one of the most morphologically and ecologically diverse flowering plant families native to the tropics and subtropics of the New World (Givnish et al., 2011).

Traditionally, this family has been divided into three subfamilies: Bromelioideae, Pitcairnioideae, and Tillandsioideae, based on Cronquist (1988). However, Givnish et al. (2011) confirmed a phylogeny based on eight plastid regions, with the new classification including eight subfamilies: (Brochinioideae, Lindmanioideae, Tillandsioideae, Hechtioideae, Navioideae, Pitcairnioideae, Puyoideae, and Bromelioideae) according to the morphological characteristics of flowers, fruits, and seeds, and on molecular data (Givnish et al., 2007; Givnish et al., 2011).

Plants in the Bromeliaceae family provide excellent models for the study of genetic diversity (Zanella et al., 2012; Hmeljevski et al., 2013), population genetics (Lavor et al., 2014), as well as the divergence between populations and species (Sarthou et al., 2001; Barbará et al., 2007; Palma-Silva et al., 2009). Bromeliads are an important and characteristic element of Neotropical forests, especially in the Brazilian Atlantic Forest (BAF), where they are among those families with the greatest richness and diversity (Martinelli et al., 2008).

Nevertheless, relatively few genetic studies have examined Neotropical plant species and investigated genetic aspects of BAF bromeliads by comparing temperate forests (Cavallari et al., 2006; Barbará et al., 2007; Palma-Silva et al., 2009; Versieux et al., 2012; Zanella et al., 2012; Lavor et al., 2014; Goetze et al., 2015). According to Zanella et al. (2012), only 20 species of the following nine genera have been previously evaluated, and most of the studied species are endemic to the Atlantic rainforest in southeastern Brazil: Aechmea, Alcantarea, Bromelia, Dyckia, Encholirium, Pitcairnia, Puya, Tillandsia, and Vriesea.

However, this biome has been severely destroyed and reduced to only $13 \%$ approximately of its original area, which is the main threat to BAF flora and fauna (Ribeiro, 2009). Despite this fragmentation, Martinelli et al. (2008), identified the state of Espírito Santo

Genetics and Molecular Research 16 (2): gmr16029636 
as the second largest region for species richness and endemism of this family in the Atlantic Forest; however, it is considered one of the families with the highest number of threatened taxa in the state (Kollmann et al., 2007).

According to Cavallari et al. (2006), the conservation of genetic diversity has become the goal of many conservation programs, and knowledge of the distribution of such diversity within and among natural populations is the first step in this process. Therefore, research on population genetic diversity is essential to provide information on the risk of species extinction and to design effective conservation strategies (Frankham et al., 2002). In this context, molecular markers are widely used for studying genetic variability (Cavallari et al., 2006; Barbará et al., 2007, 2009; Lavor et al., 2014; Goetze et al., 2015), and several markers have been developed for Bromeliaceae: Pitcairnia (Sarthou et al., 2003; Paggi et al., 2008), Alcantarea (Palma-Silva et al., 2007), Dyckia (Zanella et al., 2012), Encholirium (Hmeljevski et al., 2013), Orthophytum (Aoki-Gonçalves et al., 2014), and recently, Vriesea (Neri et al., 2015).

Here, we evaluate the genetic structure of five populations of the Bromeliaceae family, including specimens of the genera Aechmea, Billbergia (subfamily Bromelioideae), and Pitcairnia (subfamily Pitcairnioidea). In addition, we identified and quantified genetic variability using simple sequence repeat (SSR) markers previously validated by Miranda et al. (2012).

\section{MATERIAL AND METHODS}

\section{Study site and sample collection}

The collection sites were located in the priority ecological corridor Burarama - Pacotuba Cafundó, established in 2004 by the Project Ecological Corridors of the Institute for the Environment of the Espírito Santo state (IEMA). The purpose of this project is to connect the private reserve of the natural patrimony Cafundó Farm to the Pacotuba National Forest, with a view to decrease the effects of fragmentation in the Atlantic Forest (Projeto Corredores Ecológicos, 2006).

Populations of five species were sampled in the locality Burarama I: 32 Aechmea ramosa individuals $\left(20^{\circ} 40^{\prime} 30.83 \mathrm{\prime S}\right.$ and $\left.41^{\circ} 20^{\prime} 57.01^{\prime \prime} \mathrm{W}\right)$ and 35 Aechmea nudicaulis individuals $\left(20^{\circ} 40^{\prime} 30.83^{\prime \prime S}\right.$ and $\left.41^{\circ} 20^{\prime} 57.01^{\prime \prime W}\right)$; locality Burarama II: 31 Billbergia horrida individuals $\left(20^{\circ} 40^{\prime} 20.1^{\prime \prime S}\right.$ and $\left.41^{\circ} 22^{\prime} 35.8^{\prime \prime} \mathrm{W}\right)$ and 26 Billbergia euphemiae individuals (204'24.4"S and $41^{\circ} 20^{\prime} 55.2^{\prime \prime} \mathrm{W}$ ); and finally, locality Burarama III: 40 Pitcairnia flammea individuals $\left(20^{\circ} 40^{\prime} 52.39^{\prime \prime} \mathrm{S}\right.$ and $\left.41^{\circ} 20^{\prime} 43.38^{\prime \prime} \mathrm{W}\right)$, all located in Atlantic Forest remnants in southern Espírito Santo State (Brazil). One voucher for each species (accession No. 5569, 55681, 55657, 55664, and 55660) was deposited in the CESJ Herbarium at Universidade Federal de Juiz de Fora (UFJF).

\section{Microsatellite markers}

We evaluation of SSR markers for two loci markers originally developed for Pitcairnia geysksii by Sarthou et al. (2003) and eight for Pitcairnia albiflos (Paggi et al., 2008). These markers were previously evaluated by Miranda et al. (2012) and were found to be heterologous in amplification assays of A. ramosa, A. nudicaulis, B. horrida, B. euphemiae, and P. flammea.

\section{DNA extraction and amplification conditions}

Samples of leaf tissue from each plant were used for DNA extraction and purification

Genetics and Molecular Research 16 (2): gmr16029636 
as described by Doyle and Doyle (1990). Polymerase chain reaction (PCR) amplifications were performed in a $15-\mu \mathrm{L}$ volume containing $0.4 \mu \mathrm{M}$ each primer, $1 \mathrm{U}$ Taq DNA polymerase, 0.1 $\mathrm{mM}$ each dNTP, $10 \mathrm{mM}$ Tris-HCl pH 8.3, $50 \mathrm{mM} \mathrm{KCl}, 2 \mathrm{mM} \mathrm{MgCl}$, and 30 ng template DNA. Amplifications were performed with a Veriti Thermal Cycler (Applied Biosystems) using a cycling program of $5 \mathrm{~min}$ at $94^{\circ} \mathrm{C}$, followed by 35 cycles consisting of three steps: a) $1 \mathrm{~min}$ at $94^{\circ} \mathrm{C}$, b) $1 \mathrm{~min}$ at $54^{\circ} \mathrm{C}$, c) $1 \mathrm{~min}$ at $72^{\circ} \mathrm{C}$, with a final step of $7 \mathrm{~min}$ at $72^{\circ} \mathrm{C}$. Amplified fragments were separated by electrophoresis on $8 \%$ acrylamide gel containing $0.02 \mu \mathrm{g} / \mathrm{mL}$ ethidium bromide, $1 \mathrm{X}$ TBE buffer (0.89 M Tris-HCl pH 8.3, $0.89 \mathrm{M}$ boric acid, and $0.02 \mathrm{M}$ EDTA), at $110 \mathrm{~V}$ for approximately $4 \mathrm{~h}$. At the end of the run, the gels were photographed under ultraviolet light.

\section{Data analysis}

The acrylamide gels were analyzed to determine the genetic diversity of each locus, and the population was evaluated using the following descriptive summary statistics: allelic richness $(\mathrm{R})$, number of alleles $(\mathrm{A})$, observed $\left(H_{\mathrm{O}}\right)$ and expected $\left(H_{\mathrm{E}}\right)$ heterozygosity, fixation index (F), and Hardy-Weinberg equilibrium (HWE) using GenALEx (Peakall and Smouse, 2006). The MStools program (Park, 2001) was used to calculate the polymorphic information content (PIC) within populations.

\section{RESULTS}

The values of parameters obtained for SSRs in each of the populations are presented in Table 1.

Table 1. Global microsatellite values for each population and estimates of genetic variability, based on Nei (1973).

\begin{tabular}{|c|c|c|c|c|c|c|c|c|c|c|}
\hline Population & & PaA05 & PaA10 & PaB11 & $\mathrm{PaB} 12$ & $\mathrm{PaC} 05$ & PaD07 & PaZ01 & Pit05 & \\
\hline \multirow[t]{7}{*}{ Aechmea ramose $(\mathrm{N}=32)$} & $\hat{\mathrm{A}}$ & 2 & 2 & 3 & 5 & 2 & 4 & 4 & 3 & \\
\hline & $H_{\mathrm{O}}$ & 0.285 & 0.300 & 0.500 & 0.187 & 0.125 & 0.781 & 1.000 & 0.074 & \\
\hline & $H_{\mathrm{E}}$ & 0.249 & 0.304 & 0.436 & 0.670 & 0.436 & 0.637 & 0.654 & 0.519 & \\
\hline & PIC & 0.214 & 0.254 & 0.350 & 0.611 & 0.337 & 0.557 & 0.575 & 0.435 & \\
\hline & $\mathrm{F}$ & -0.167 & -0.002 & -0.164 & 0.709 & -0.245 & -0.554 & 0.855 & 0.716 & \\
\hline & HWE & 0.378 & 0.992 & 0.290 & 0.523 & $0.000^{*}$ & $0.000^{*}$ & $0.000^{*}$ & $0.000^{*}$ & \\
\hline & & PaA10 & $\mathrm{PaB} 12$ & $\mathrm{PaC05}$ & PaZ01 & Pit05 & & & & \\
\hline \multirow[t]{7}{*}{ Aechmea nudicaulis $(\mathrm{N}=35)$} & $\hat{A}$ & 2 & 3 & 4 & 6 & 4 & & & & \\
\hline & $H_{\mathrm{O}}$ & 0.714 & 0.178 & 0.323 & 0.875 & 0.787 & & & & \\
\hline & $H_{\mathrm{E}}$ & 0.480 & 0.168 & 0.548 & 0.808 & 0.628 & & & & \\
\hline & PIC & 0.362 & 0.156 & 0.491 & 0.765 & 0.554 & & & & \\
\hline & $\mathrm{F}$ & -0.507 & -0.081 & 0.401 & -0.100 & -0.274 & & & & \\
\hline & HWE & $0.003 *$ & 0.966 & 0.054 & $0.000^{*}$ & 0.221 & & & & \\
\hline & & PaA05 & PaB11 & PaB12 & $\mathrm{PaC05}$ & PaD07 & PaZ01 & Pit05 & & \\
\hline \multirow[t]{7}{*}{ Billbergia horrida $(\mathrm{N}=31)$} & $\hat{\mathrm{A}}$ & 2 & 2 & 4 & 2 & 6 & 4 & 3 & & \\
\hline & $H_{\mathrm{O}}$ & 0.300 & 0.656 & 0.300 & 0.100 & 0.758 & 0.684 & 0.677 & & \\
\hline & $H_{\mathrm{E}}$ & 0.260 & 0.507 & 0.637 & 0.096 & 0.743 & 0.689 & 0.571 & & \\
\hline & PIC & 0.222 & 0.374 & 0.565 & 0.905 & 0.693 & 0.619 & 0.501 & & \\
\hline & $\mathrm{F}$ & -0.176 & -0.314 & 0.521 & -0.053 & -0.040 & -0.019 & -0.204 & & \\
\hline & HWE & 0.334 & 0.076 & $0.000^{*}$ & 0.776 & $0.000^{*}$ & 0.040 & & & \\
\hline & & PaA05 & PaA09 & PaA10 & PaB12 & $\mathrm{PaC} 05$ & PaD07 & PaZ01 & Pit05 & Pit09 \\
\hline \multirow[t]{7}{*}{ Billbergia euphemia $(\mathrm{N}=26)$} & $\hat{A}$ & 2 & 2 & 2 & 2 & 2 & 6 & 4 & 4 & 3 \\
\hline & $H_{\mathrm{O}}$ & 0.434 & 0.476 & 0.44 & 0.000 & 0.238 & 0.791 & 0.391 & 0.391 & 0.347 \\
\hline & $H_{\mathrm{E}}$ & 0.347 & 0.371 & 0.392 & 0.435 & 0.396 & 0.826 & 0.607 & 0.561 & 0.501 \\
\hline & PIC & 0.282 & 0.297 & 0.310 & 0.335 & 0.311 & 0.781 & 0.550 & 0.487 & 0.418 \\
\hline & $\mathrm{F}$ & -0.278 & -0.313 & -0.143 & 1.000 & 0.384 & 0.021 & 0.342 & 0.284 & 0.291 \\
\hline & HWE & 0.183 & 0.152 & 0.473 & $0.000^{*}$ & 0.078 & $0.000^{*}$ & $0.000^{*}$ & $0.001^{*}$ & 0.131 \\
\hline & & PaA05 & PaA09 & PaA10 & PaB11 & $\mathrm{PaB} 12$ & $\mathrm{PaC05}$ & PaD07 & $\mathrm{PaZ} 01$ & Pit05 \\
\hline \multirow[t]{6}{*}{ Pitcairnia flammea $(\mathrm{N}=40)$} & $\hat{A}$ & 4 & 5 & 3 & 2 & 3 & 4 & 4 & 3 & 4 \\
\hline & $H_{\mathrm{O}}$ & 0.941 & 0.825 & 0.025 & 0.575 & 0.947 & 0.645 & 0.948 & 0.923 & 1.000 \\
\hline & $H_{\mathrm{E}}$ & 0.586 & 0.649 & 0.073 & 0.414 & 0.544 & 0.708 & 0.554 & 0.530 & 0.545 \\
\hline & PIC & 0.489 & 0.572 & 0.071 & 0.325 & 0.429 & 0.646 & 0.445 & 0.410 & 0.430 \\
\hline & $\mathrm{F}$ & -0.628 & -0.286 & 0.657 & -0.404 & -0.764 & 0.074 & -0.733 & -0.764 & -0.860 \\
\hline & HWE & 0.103 & 0.234 & 0.057 & 0.043 & 0.072 & 0.124 & 0.203 & 0.178 & 0.275 \\
\hline
\end{tabular}

$* \mathrm{P}<0.05 . \hat{\mathrm{A}}=$ number of alleles per locus; $H_{\mathrm{O}}=$ observed heterozygosity; $H_{\mathrm{E}}=$ expected heterozygosity under Hardy-Weinberg; $\mathrm{PIC}=$ polymorphic information content; $\mathrm{F}=$ fixation index; $\mathrm{HWE}=$ Hardy-Weinberg equilibrium; $\mathrm{n}=$ number of individuals.

Genetics and Molecular Research 16 (2): gmr16029636 
The number of alleles per locus in each population ranged from two to six. The expected and observed heterozygosity ranged from 0.073 (PaA10 in $P$. flammea) to 0.826 (PaD07 in $B$. euphemia), and from 0.000 (PaB12 in B. euphemia) to 1.000 (PaZ01 in A. ramosa and Pit05 in $P$. flammea population) respectively. The polymorphic information content ranged from 0,071 ( $\mathrm{PaA} 10$ in P. Alammea population) to 0.905 ( $\mathrm{PaC} 05$ in $B$. horrida population), and some markers obtained were highly informative (PIC $>0.5$ ). For example, PIC values of 0.765 (PaZ01 in A. nudicaulis) and 0.781 (PaD07 in Billbergia) were obtained. The fixation index (F), estimated at some SSR in bromeliad populations was less than zero in all populations. SSRs in the $B$. horrida population (except for PaB12) promote inbred escape (outbreeding); the opposite was observed, such that some loci are inbred (e.g., from 0.657 to in the PaA10 $P$. flammea population), or the genotypic frequencies in these alleles within populations are not in Hardy-Weinberg equilibrium.

Regarding the estimation of HWE for each locus, only P. flammea populations exhibited markers that were all in HWE $(\mathrm{P}<0.05)$. Average intra-population genetic diversity was assessed for each species, and was also demonstrated by estimating allelic richness, heterozygosity, PIC, and fixation index in Table 2.

Table 2. Genetic parameters obtained for each species.

\begin{tabular}{l|c|c|c|c|c}
\hline Species & $R s$ & $H_{\mathrm{O}}$ & $H_{\mathrm{E}}$ & PIC & F \\
\hline Aechmea ramosa & 3.12 & 0.407 & 0.481 & 0.416 & 0.143 \\
\hline Aechmea nudicaulis & 3.16 & 0.576 & 0.519 & 0.465 & -0.110 \\
\hline Billbergia horrida & 3.00 & 0.430 & 0.435 & 0.554 & -0.041 \\
\hline Billbergia euphemia & 3.00 & 0.390 & 0.483 & 0.419 & 0.177 \\
\hline Pitcairnia flammea & 3.55 & 0.759 & 0.505 & 0.424 & -0.112 \\
\hline
\end{tabular}

$R s=$ allelic richness; $H_{\mathrm{O}}=$ observed heterozygosity; $H_{\mathrm{E}}=$ expected heterozygosity under Hardy-Weinberg; PIC $=$ polymorphic information content; $\mathrm{F}$ = fixation index.

Regarding genetic diversity parameters, allelic richness ranged from 3.55 (P. flammeal locality Burarama III) to 3.00 (B. horrida and B. euphemia/locality Burarama II); expected heterozygosity ranged from 0.435 (B. horrida) to 0.519 (A. nudicaulis), and the fixation index was between -0.110 (A. nudicaulis) and 0.177 (B. euphemia). Furthermore, in the present study, the SSRs utilized were efficient at indicating moderate-to-high polymorphism between species, as described by Xie et al. (2010).

\section{DISCUSSION}

Overall, the 10 microsatellites used amplified some of the Bromeliad species evaluated in this study. Most of these markers were polymorphic, with the exception of PaD07A and PaA10, which were monomorphic for the populations of $A$. nudicaulis and $B$. horrida, respectively.

The inbreeding populations for $A$. nudicaulis $(\mathrm{F}=-0.110)$, B. horrida $(\mathrm{F}=-0.041)$, and P. flammea $(\mathrm{F}=-0.122)$ may be considered null, since $95 \% \mathrm{CI}$ of the estimates was not significant, that is, it includes zero. Considering panmixia and HWE, similar results were obtained in previous studies of population genetic diversity for A. regina $(\mathrm{F}=-0.051)$ (Barbará et al., 2009) and $P$. geysksii $(\mathrm{F}=-0,037)$ (Sarthou et al., 2001).

Moreover, significant deviations from Hardy-Weinberg equilibrium were observed in some loci from populations belonging to the five bromeliad species (Table 1). In most cases, this can be attributed to the presence of inbreeding or to the Wahlund effect (Hartl and Clark,

Genetics and Molecular Research 16 (2): gmr16029636 
1997). In populations with the highest number of loci with deviations ( $A$. ramosa and $B$. euphemia), significant values were also found for fixation indexes, giving positive values for intrapopulation inbreeding.

The genetic diversity indices of five species showed there is greater allelic richness in P. flammea (3.55). This is due to the larger sample size of the population, with 40 individuals. Furthermore, the sampled area (Burarama III) was difficult to access, with the presence of dense forest, which is in contrast to other sampled locations (Burarama I and II), in which different degrees of human action were observed.

Regarding the overall distribution of genotypes, the observed and expected heterozygosities were similar (Table 2). Unlike the pattern found for Alcantarea imperialis (Carrière) JR Grant and Aechmea geniculata (Wawra) JR Grant (Barbará et al., 2007), in Vriesea gigantea (Palma-Silva et al., 2009), and also Vriesea minarum (Lavor et al., 2014), the observed heterozygosity was lower than expected because of a deficit of heterozygotes. These data further suggest that an excess of homozygotes could be due to selfing or biparental inbreeding, since $V$. minarum exhibits a mixed reproductive strategy (outcrossing + self-compatibility), or due to a feature of the subfamily Tillandsioideae. Matallana et al. (2010) suggested that A. nudicaulis, B. horrida, and B. euphemia have self-incompatible (SI) mating systems, which promote allogamy, representing positive and various empirical models that suggest outinbreeding that is evolutionarily advantageous due to selective pressures favoring genetic variability. Moreover, Pitcairnia flammea according to Wendt et al. (2002), presents reproduction type of self-compatible or partially self-compatible. Our data support the presence of substantial genetic diversity among populations of $A$. ramosa, $A$. nudicaulis, B. horrida, B. euphemia, and P. flammea.

These findings provide useful information for the characterization of genetic diversity in natural populations of A. ramosa, A. nudicaulis, B. horrida, B. euphemia, and P. flammea in the Atlantic Forest remnants in the south of Espírito Santo state. According to Bizoux and Mahy (2007), clonal and sexual reproduction, demography, genetic structure within and among populations, gene flow, and mating systems of bromeliads are important for the development of successful conservation strategies. These data on the genetic diversity and distribution of genotypes among populations are essential for determining the conservation status of species and may be used for decision making regarding the delineation of protected areas.

\section{Conflicts of interest}

The authors declare no conflict of interest.

\section{ACKNOWLEDGMENTS}

The authors thank the Coordenação de Aperfeiçoamento de Pessoal de Nível Superior, CAPES, and Fundação de Amparo à Pesquisa do Estado de Espírito Santo, FAPES for funding the project. This work was carried out at the Molecular Biology Laboratory of the Federal University of Espírito Santo.

\section{REFERENCES}

Aoki-Gonçalves F, Louzada RB, De Souza LM and Palma-Silva C (2014). Microsatellite loci for Orthophytum ophiuroides (Bromelioideae, Bromeliaceae) species adapted to neotropical rock outcrops. Appl. Plant Sci. 2: 1-4. http://dx.doi. org/10.3732/apps.1300073

Genetics and Molecular Research 16 (2): gmr16029636 
Barbará T, Palma-Silva C, Paggi GM, Bered F, et al. (2007). Cross-species transfer of nuclear microsatellite markers: potential and limitations. Mol. Ecol. 16: 3759-3767. http://dx.doi.org/10.1111/j.1365-294X.2007.03439.x

Barbará T, Martinelli G, Palma-Silva C, Fay MF, et al. (2009). Genetic relationships and variation in reproductive strategies in four closely related bromeliads adapted to neotropical 'inselbergs': Alcantarea glaziouana, A. regina, A. geniculata and A. imperialis (Bromeliaceae). Ann. Bot. (Lond.) 103: 65-77. http://dx.doi.org/10.1093/aob/mcn226

Benzing DH (2000). Bromeliaceae: Proðle of an Adaptive Radiation. London: Cambridge Univ. Press, Cambridge.

Bizoux JP and Mahy G (2007). Within-population genetic structure and clonal diversity of a threatened endemic metallophyte, Viola calaminaria (Violaceae). Am. J. Bot. 94: 887-895. http://dx.doi.org/10.3732/ajb.94.5.887

Cavallari MM, Forzza RC, Veasey EA, Zucchi MI, et al. (2006). Genetic variation in three endangered species of Encholirium (Bromeliaceae) from Cadeia do Espinhaço, Brazil, detected using RAPD markers. Biodivers. Conserv. 15: 4357-4373. http://dx.doi.org/10.1007/s10531-005-3741-5

Cronquist A (1988). The evolution and classification of flowering plants. 2a. ed. New York Botanic Garden, New York.

Doyle JJ and Doyle JL (1990). Isolation of plant DNA from fresh tissue. Focus 12: 13-15.

Frankham R, Ballou JD and Briscoe DA (2002). Introduction to conservation genetics. Cambridge University Press, Cambridge, UK.

Givnish TJ, Millam KC, Berry PE and Sytsma KJ (2007). Phylogeny, adaptive radiation, and historical biogeography of Bromeliaceae inferred from sequence data. In: Monocots: Comparative Biology and Evolution: Poales (Columbus JT, Friar EA, Porter JM, Prince LM, et al., eds.). Rancho Santa Ana Botanic Garden, Claremont.

Givnish TJ, Barfuss MHJ, Van Ee B, Riina R, et al. (2011). Phylogeny, adaptive radiation, and historical biogeography in Bromeliaceae: insights from an eight-locus plastid phylogeny. Am. J. Bot. 98: 872-895. http://dx.doi.org/10.3732/ ajb. 1000059

Goetze M, Buttow MV, Zanella CM, Paggi GM, et al. (2015). Genetic variation in Aechmea winkleri, a bromeliad from an inland Atlantic rainforest fragment in Southern Brazil. Biochem. Syst. Ecol. 58: 204-210. http://dx.doi.org/10.1016/j. bse.2014.12.010

Hartl DL and Clark AG (1997). Principles of Population Genetics. Sinauer \& Associates, Sunderland, Massachusetts.

Hmeljevski KV, Ciampi MB, Baldauf C, Sedrez Dos Reis M, et al. (2013). Development of SSR markers for Encholirium horridum (Bromeliaceae) and transferability to other Pitcairnioideae. Appl. Plant Sci. 1: 1-4. http://dx.doi. org/10.3732/apps.1200445

Kollmann LJC, Fontana AP, Simonelli M and Fraga CN (2007). As Angiospermas ameaçadas de extinção no estado do Espírito Santo. In: Espécies da flora ameaçadas de extinção no estado Espírito Santo (Fraga CN and Simonelli M, eds.). IPEMA, Vitória.

Lavor P, van den Berg C, Jacobi CM, Carmo FF, et al. (2014). Population genetics of the endemic and endangered Vriesea minarum (Bromeliaceae) in the iron quadrangle, Espinhaço range, Brazil. Am. J. Bot. 101: 1167-1175. http://dx.doi. org/10.3732/ajb.1300388

Luther HD (2008). An Alphabetical List of Bromeliad Binomials. The Bromeliad Society International, Sarasota, Florida.

Martinelli G, Vieira CM, Gonzalez M, Leitma P, et al. (2008). Bromeliaceae da Mata Atlântica Brasileira: lista de espécies, distribuição e conservação. Rodriguésia 59: 209-258.

Matallana G, Godinho ASM, Guilherme FAG, Belisario M, et al. (2010). Breeding systems of Bromeliaceae species: Evolution of selfing in the context of sympatric occurrence. Plant Syst. Evol. 289: 57-65. http://dx.doi.org/10.1007/ $\underline{\mathrm{s} 00606-010-0332-\mathrm{z}}$

Miranda FD, Gontijo ABPL, Santiliano FC, Favoreto FC, et al. (2012). Transferability and characterization of microsatellite markers in five Bromeliaceae species belonging to the subfamilies Pitcairnioideae and Bromelioideae. Biota Neotrop. 12: 319-323. http://dx.doi.org/10.1590/S1676-06032012000300032

Nei M (1973). Analysis of gene diversity in subdivided populations. Proc. Natl. Acad. Sci. USA 70: 3321-3323. http:// dx.doi.org/10.1073/pnas.70.12.3321

Neri J, Nazareno AG, Wendt T and Palma-Silva C (2015). Development and characterization of microsatellite markers for Vriesea simplex (Bromeliaceae) and cross-amplification in other species of Bromeliaceae. Biochem. Syst. Ecol. 58: 34-37. http://dx.doi.org/10.1016/j.bse.2014.10.004

Paggi GM, Palma-Silva C, Bered F, Cidade FW, et al. (2008). Isolation and characterization of microsatellite loci in Pitcairnia albiflos (Bromeliaceae), an endemic bromeliad from the Atlantic Rainforest, and cross-amplification in other species. Mol. Ecol. Resour. 8: 980-982. http://dx.doi.org/10.1111/j.1755-0998.2008.02126.x

Palma-Silva C, Cavallari MM, Barbara T, Lexer C, et al. (2007). A set of polymorphic microsatellite loci for Vriesea gigantea and Alcantarea imperialis (Bromeliaceae) and cross-amplification in other bromeliad species. Mol. Ecol. Notes 7: 654-657. http://dx.doi.org/10.1111/j.1471-8286.2006.01665.x

Palma-Silva C, Lexer C, Paggi GM, Barbará T, et al. (2009). Range-wide patterns of nuclear and chloroplast DNA

Genetics and Molecular Research 16 (2): gmr16029636 
diversity in Vriesea gigantea (Bromeliaceae), a neotropical forest species. Heredity (Edinb) 103: 503-512. http:// dx.doi.org/10.1038/hdy.2009.116

Park SDE (2001). Trypanotolerance in West African Cattle and the Population Genetic Effect of Selection. Ph.D. thesis, Univ. of Dublin.

Peakall R and Smouse PE (2006). Genalex 6: genetic analysis in excel. population genetic software for teaching and research. Mol. Ecol. Notes 6: 288-295. http://dx.doi.org/10.1111/j.1471-8286.2005.01155.x

Projeto Corredores Ecológicos (2006). Síntese do processo de definição e planejamento dos corredores prioritários no Espírito Santo/Projeto Corredores Ecológicos, Cariacica.

Ribeiro PCC (2009). Diversidade e estrutura genética de três espécies de Bromeliaceae ameaçadas de extinção. Master’s dissertation. Universidade Federal de Juiz de Fora Juiz de Fora, Minas Gerais. Available at [http://www.bdtd.ufjf.br/ tde_busca/arquivo.php?codArquivo=562]. Accessed January 30, 2015

Sarthou C, Samadi S and Boisselier-Dubayle MC (2001). Genetic structure of the saxicole Pitcairnia geyskesii (Bromeliaceae) on inselbergs in French Guiana. Am. J. Bot. 88: 861-868. http://dx.doi.org/10.2307/2657038

Sarthou C, Boisselier-Dubayle MC, Lambourdiere J and Samadi S (2003). Polymorphic microsatellites for the study of fragmented populations of Pitcairnia geyskesii L. B. a specific saxicolous species of inselbergs in French Guiana. Mol. Ecol. Notes 3: 221-223. http://dx.doi.org/10.1046/j.1471-8286.2003.00404.x

Versieux LMT, Barbará T, Wanderley Md, Calvente A, et al. (2012). Molecular phylogenetics of the Brazilian giant bromeliads (Alcantarea, Bromeliaceae): implications for morphological evolution and biogeography. Mol. Phylogenet. Evol. 64: 177-189. http://dx.doi.org/10.1016/j.ympev.2012.03.015

Wendt TM, Canela BF, Klein DE and Rios RI (2002). Selfing facilitates reproductive isolation among three sympatric species of Pitcairnia (Bromeliaceae). Plant Syst. Evol. 232: 201-212. http://dx.doi.org/10.1007/s006060200043

Xie WG, Zhang XQ, Cai HW, Liu W, et al. (2010). Genetic diversity analysis and transferability of cereal EST-SSR markers to orchardgrass (Dactylis glomerata L.). Biochem. Syst. Ecol. 38: 740-749. http://dx.doi.org/10.1016/j. bse.2010.06.009

Zanella CM, Janke A, Palma-Silva C, Kaltchuk-Santos E, et al. (2012). Genetics, evolution and conservation of Bromeliaceae. Genet. Mol. Biol. 35 (4 Suppl): 1020-1026. http://dx.doi.org/10.1590/S1415-47572012000600017

Genetics and Molecular Research 16 (2): gmr16029636 